\title{
Effect of liquid Biofertilizer (Vrikshayurveda) prepared from Brassica alba on the cultivation of rice
}

\author{
A njan K umar Sinha* and P. K. M ishra \\ Department of Botany, Vinoba Bhave University, Hazaribag-825 301 (Jharkhand), INDIA \\ *Corresponding author. E-mail: anjansinha06@ gmail.com
}

Received: September 11, 2013; Revised received: 0 ctober 12, 2013; Accepted: 0 ctober 15, 2013

\begin{abstract}
Brassica alba, one of the very anciently well known plants, was used as biofertilizer long time before. Pot culture technique was introduced and three different pots were prepared. Plants of first pot provided only normal dose of urea, in second pot additionally $10 \%$ B. alba liquid manure sprayed along with the normal dose of urea. Third pot was provided with blue green algal fertilization and $10 \%$ of B. alba liquid manure. Various parameters like plant height, leaf length, leaf number and inflorescence length were evaluated in test culture receiving different dose of urea and bio-fertilizer. In pot-1, plant height, length of inflorescence, grain yield, husk yield, grains per panicle , number of panicle per plant and weight of 1000 grains was found to be $84.30 \mathrm{~cm}, 19.50 \mathrm{~cm}, 2800 \mathrm{kgha}^{-1}$, $4300 \mathrm{kgha}^{-1}, 42$ grains per panicle, 4 panicle and $24.80 \mathrm{gm}$ respectively, whereas in pot-2 plant height, length of inflorescence, grain yield, husk yield, grains per panicle, number of panicle per plant and weight of 1000 grains was found to be $98.50 \mathrm{~cm}, 21.40 \mathrm{~cm}, 3700 \mathrm{kgha}^{-1}, 5600 \mathrm{kgha}^{-1}, 56$ grains, 6 panicle and $29.30 \mathrm{gm}$ respectively and in test pot-3, plant height, length of inflorescence, grain yield, husk yield, grains per panicle, number of panicle per plant and weight of 1000 grains was found to be $112.80 \mathrm{~cm}, 24.30 \mathrm{~cm}, 3850 \mathrm{~kg} \mathrm{ha}^{-1}, 5630 \mathrm{kgha}^{-1}, 60$ grain per panicle, 6 panicle, and $30.60 \mathrm{gm}$ respectively. The results clearly indicated that in comparison to urea, B. alba treated paddy plant performed higher plant height, higher yield production, higher husk production, larger number of grain per panicle and panicle length and higher grain weight.
\end{abstract}

Keywords: Biofertilizer, Brassica alba, Rice, Vrikshayurveda

\section{INTRODUCTION}

For almost last fifty years Indian agriculture has mainly concentrated on increasing yield and to achieve this goal synthetic chemicals have been utilized as fertilizers, pesticides and growth regulators (Mishra 2007). This in turn has treated many environmental problems which include contamination of surface as well as ground water problem of carry over and soil becoming barren. This has led to dawn of a new concept of organic farming where plant and animal based fertilizers farming where plant and animal based fertilizers are preferred over synthetic chemicals (Sadhale 1996). It is highly encouraging that in India there are several prescriptions for enhancing growth of crop plants which are plant and animal based and have been compiled as a lesser know book Vrikshayurveda (Pathi Lakshmi, 1960; Jugnu, 2004). "Vrikshayurveda" has become widely known amongst agriculturists not only in India but also in other countries. In fact the term "Vrikshayurveda" has been in use since ancient times. From the time of Kautilya (296-321 BC) to the 13th-century AD "Vrikshayurveda" was compiled, composed and written by the different ancient authors (Nene 2012). In 505-581 AD "Vrikshayurveda" complied in "Brhat Samhita" by Varahamihira. Surapala composed
Vrikshayurveda in 1000 A.D. and Chavundaraya (1025) composed Vrikshayurveda chapter in Lokopakara. In the 12 th century AD, Chalukya King, Someshvardeva compiled an encyclopedia "Abhilashitarthachitamani" or "Manasollasa" in which a full chapter on Vrikshayurveda was included (Jugunu, 2004). Vrikshayureveds, literally means "science of plants' and it included as much as 325 suggestions of organic farming. In prescription numbers 116,117 and 118 possible use of Brassica alba extract as growth enhancer has been highlighted and present study was aimed to study the effect of liquid classical biofertilizer (Vrikshayurveda) prepared from B. alba on the cultivation of rice.

\section{MATERIALS AND METHODS}

A $1 \mathrm{~kg}$ of B. alba whole plant was boiled with 10 liters of water for 30 minutes and the liquid was allowed to cool. The filtrated was used as liquid growth regulator in the experiment. Rice seeds of Vandana variety were used in three sets of pot culture. Rice seeds were allowed to germinate and 10 days old seedlings were transplanted in test pots. Control pot was provided normal dose of urea only. The second pot was also provide normal dose of urea by additionally sprayed $10 \%$ Brassica alba liquid manure. Third pot was provided blue green algal 
fertilization and 10\% of Brassica alba liquid manure (Table 1). Yield attributes were estimated after 90 days. Data recorded were analyzed statistically.

\section{RESULTS AND DISCUSSION}

Morphological parameters of plants of three different pot condition have been given in table 2 . In control condition, average plant height was found to be $84.30 \mathrm{~cm}$ whereas urea treated and growth enhancer sprayed plants grew up to $98.50 \mathrm{~cm}$. Blue green algal treated and growth enhancer plants exhibited growth of $112.80 \mathrm{~cm}$. Length of inflorescence in control condition was found to be $19.50 \mathrm{~cm}$. Whereas in experimental condition two and three length of inflorescence was recorded $21.40 \mathrm{~cm}$ and $24.30 \mathrm{~cm}$ respectively. Grain yield was noted to be 2800 $\mathrm{kgha}^{-1}$ whereas urea-growth enhancer condition helped increase grain yield up to $3700 \mathrm{kgha}^{-1}$. Test pot having blue green algae-growth enhancer condition gave 3850 $\mathrm{kg} \mathrm{ha}^{-1}$ yield. Husk yield was recorded to be $4300 \mathrm{kgha}^{-1}$ in control condition whereas the two growth enhancer treated condition exhibited 5600 and 5630 respectively. Rice plant of control condition produced 42 grains per panicle whereas in two growth enhancer treated condition 56 and 60 grain per panicle were recorded. So far number of panicle per plant was concerned the value was 4 in control condition and 6 in both experimental pots treated with $B$. alba growth enhancer. Weight of 1000 grains was $24.80 \mathrm{gm}$ in control condition; grains of urea-growth enhancer plant weighted 29.30 gm where as weight of grains in blue green algae-liquid manual condition was $30.60 \mathrm{gm}$.

Results clearly indicated that B.alba extract acted as growth stimulator of paddy. Stimulation effect was more pronounced in combination with blue green algae. Both growth parameters were well as yield attributes showed encouraging results. Plant based growth stimulation in rice has been described by other workers as well (Mishra,
2007; Khan and Vashistha, 1998). B. alba based growth enhancer is both cost effective as well as ecofriendly.

Its use in paddy fields should be encouraged. A field experiment was conducted by Chand et al. (2006) for seven years continuously to evaluate the influence of combined applications and organic and chemical fertility build up and nutrient uptake in a mint ( $M$ entha arvensis) and mustard (Brassica juncea) cropping sequence. Results indicated that integrated supply of plant nutrients through farmyard manure (FYM) and fertilizer NPK, along with Sesbania green manuring, played a significant role in sustaining soil fertility and crop productivity. Based on the evaluation of soil quality indicators, Dutta et al. (2003) reported that the use of organic fertilizers together with chemical fertilizers, compared to the addition of organic fertilizers alone, had a higher positive effect on microbial biomass and hence soil health. Application of organic manure in combination with chemical fertilizer has been reported to increase absorption of $\mathrm{N}, \mathrm{P}$ and $\mathrm{K}$ in sugarcane leaf tissue in the plant and ration crop, compared to chemical fertilizer alone (Bokhtiar and Sakurai, 2005).

\section{Conclusion}

The use of synthetic manure in agricultural field is a very serious problem in present era of modern agricultural system both economically and environmentally. It is argent to introduce organic manure in agricultural field to protect agricultural ecosystem. Therefore, a balanced fertilization strategy that combines the use of chemical, organic or bio fertilizers must be developed and evaluated. B. alba liquid manure suggested in Vrikshayurveda, showed significant and profound effect on growth and development in rice plant. Out of various growth parameters, B. alba liquid manure and Blue green algal combination most significantly affected plant height, leaf length and inflorescence length. The traditional agricultural knowledge, as informed

Table 1. Test pot culture condition with different percentage of Urea, B.alba and Blue-green algal fertilizer application.

\begin{tabular}{ccc}
\hline Pot 1 (contr ol) & Pot 2 & Pot 3 \\
\hline Normal dose of Urea & Urea $+10 \%$ B . alba Liquid & Blue-green algal fertilizer + \\
(100\% urea) & manure & $10 \%$ B. al ba Liquid manure \\
\hline
\end{tabular}

Table 2. Growth performance of Vandana rice variety grown in different test pot culture conditions.

\begin{tabular}{|c|c|c|c|}
\hline Parameters & Pot 1 & Pot 2 & Pot 3 \\
\hline Plant height ${ }^{1}(\mathrm{~cm})$ & $84.30 \pm 2.5^{* *}$ & $98.50 \pm 3.4^{* *}$ & $112.80 \pm 3.8^{* *}$ \\
\hline Inflorescence length $(\mathrm{cm})^{2}$ & $19.50 \pm 2.6 * *$ & $21.40 \pm 3.3^{* *}$ & $24.30 \pm 3.4^{* *}$ \\
\hline Grain yield $\left(\mathrm{kgha}^{-1) 3}\right.$ & $2800 * *$ & $4300 * *$ & $5600 * *$ \\
\hline Husk yield $\left(\mathrm{kgha}^{-1) 4}\right.$ & $4300^{* *}$ & $5600^{* *}$ & $5630^{* *}$ \\
\hline Grains per panicle ${ }^{5}$ & $42 \pm 2^{* *}$ & $56 \pm 3^{* *}$ & $60 \pm 4^{* *}$ \\
\hline Number of panicle/plant ${ }^{6}$ & $4 \pm 1^{*}$ & $6 \pm 2^{*}$ & $6 \pm 2^{*}$ \\
\hline 1000 grain weight $(\mathrm{gm})^{7}$ & $24.80 \pm 1.5^{*}$ & $29.30 \pm 2.4^{*}$ & $30.00 \pm 3.1^{*}$ \\
\hline
\end{tabular}


in Vrikshayurveda is highly scientific and relevant in present situation also. Keeping in view the adverse affect of synthetic organic fertilizers, use of natural liquid manure like B.alba can be the best option.

\section{REFERENCES}

Bokhtiar, S.M. and Sakurai, K. (2005). Effects of organic manure and chemical fertilizer on soil fertility and productivity of plant and ratoon crops of sugarcane. Archives of Agronomy and Soil Science, 51: 325-334.

Chand, S., Anwar, M. \& Patra, D.D.(2006). Influence of longterm application of organic and inorganic fertilizer to build up soil fertility and nutrient uptake in mint-mustard cropping sequence. Communications in Soil Science and Plant Analysis, 37: 63-76.

Dutta, S., Pal, R., Chakeraborty, A. and Chakrabarti, K. (2003). Influence of integrated plant nutrient supply system on soil quality restoration in a red and laterite soil. Archives of Agronomy and Soil Science, 49: 631-637.

Jugunu, S.K, (2004). Vrikshayurveda. Chowkhamba Sanskrit Series office, Varanasi. pp. 7-149.

Khan, H.A and B.B. Vashishlta, (1998). Effects of plant based growth stimulation in Rice. J . Tree. Sc., (17) 59-60.

Pathi Lakshmi, A. (1960) Vrikshayurveda. Jain Bhaskarodaya Press, Jamnagar. pp. 362-396

Mishra, P.K. ( 2007). Effect of K unapa J alam Vrikshyurveda on growth of Paddy. Ind. J. Tra K now., 6(2): 307-310.

Sadhale Nalini. (Tr.) (1996). Surapala's Vrikshayurveda (The Science of Plant Life by Surapala). Agri-History Bulletin No. 1. Asian Agri-History Foundation, Secunderabad 500009. India. pp. 94.

Nene, Y.L. (2012). Potential of some methods described in vrikshayurvedas in crop yield increase and disease management. Asian Agri H istory, 16(1): 45-54. 